\section{Case Reports in Ophthalmology}

This article is licensed under the Creative Commons Attribution-NonCommercial 4.0 International License (CC BY-NC) (http://www.karger.com/Services/OpenAccessLicense).

Usage and distribution for commercial purposes requires written permission.

\title{
Primary Marginal Zone B-Cell Lymphoma of the Mucosa-Associated Lymphoid Tissue of the Lacrimal Sac Found with Epiphora: A Case Report
}

\author{
Yoshiyuki Kitaguchi ${ }^{\mathrm{a}}$ Yasuhiro Takahashi ${ }^{\mathrm{a}} \quad$ Jacqueline Mupas-Uy $^{\mathrm{a}}$ \\ Emiko Takahashi $^{\mathrm{b}}$ Hirohiko Kakizaki ${ }^{\mathrm{a}}$ \\ aDepartment of Oculoplastic, Orbital \& Lacrimal Surgery, Aichi Medical University \\ Hospital, Nagakute, Japan; ${ }^{\mathrm{b}}$ Department of Pathology, Aichi Medical University Hospital, \\ Nagakute, Japan
}

\section{Keywords}

Lacrimal sac · MALT lymphoma $\cdot$ Epiphora $\cdot$ Magnetic resonance imaging · Immunotherapy

\begin{abstract}
We report a case of a primary marginal zone B-cell lymphoma of the mucosa-associated lymphoid tissue of the lacrimal sac, which was found in a patient with epiphora without palpable mass. Magnetic resonance imaging demonstrated mucosal thickening of the lacrimal sac with a patent lumen, consistent with the intraoperative finding. Epiphora resolved, which was confirmed by smooth syringing, 1 month after starting the immunotherapy.

\section{Introduction}

Marginal zone B-cell lymphoma of the mucosa-associated lymphoid tissue (MALT lymphoma) of the lacrimal sac is a quite rare cause of the lacrimal duct obstruction [1,2]. Typically, this entity initially presents with epiphora, followed by dacryocystitis and/or a palpa- 
ble mass [3]. A lack of specific symptoms may result in difficult diagnosis, which delays decision for biopsy. Concomitant dacryocystitis also interferes in the palpation of mass [3].

Lacrimal sac tumors are more exposed to inflammatory conditions compared to other ocular adnexal disorders [4]. MALT lymphoma may transform into a more aggressive subtype like diffuse large B cell lymphoma [4]. This suggests the importance of early diagnosis of lacrimal sac lymphomas.

The clinical features of primary MALT lymphoma of the lacrimal sac have not been well documented. We report a case of this entity found in a patient who presented merely with epiphora.

\section{Case Report}

A 38-year-old woman was referred due to an incidental finding of a mass in her right lacrimal sac on computed tomography (CT) for a subcutaneous tumor of the cheek. She had an epiphora for 2 months. There was no history of dacryocystitis, pain or swelling in this region. The tumor was not palpable even with compression. She was otherwise healthy and without any medications.

The CT image showed a mass in her right lacrimal sac without bony erosion (fig. 1a). Magnetic resonance imaging (MRI) revealed slight hyperintensity on T1-weighted and T2weighted images of the extraocular muscles, with homogenous contrast enhancement (fig. 1b-e). The lumen appeared to be patent with low intensity on T1- but bright on T2-weighted images (fig. 1c-e).

She underwent transcutaneous incisional biopsy. The outer wall of the lacrimal sac showed normal appearance. When the sac wall was opened, the lacrimal sac mucosa was markedly thickened with a patent lumen (fig. 2). Pinkish gray mucosa was noticed, and it was removed for histopathological examination. The lacrimal sac was closed by interrupted sutures using 6-0 polyglycolide (Vsorb; Kono Seisakusho Co., Ltd., Tokyo, Japan).

The histopathological examination revealed diffuse infiltration of small round to cleaved lymphocytes, consistent with MALT lymphoma (fig. 3a, b). On immunohistochemistry, the tumor cells were positive for CD20, and CD79a, but negative for bcl-2, CD3, CD5, CD10, CD23, cyclin-D1, and bcl-6 (fig. 3c, d). MIB-1-positive cells were present in 10\% of all cells. Kappa to lambda was $>1.0$. Thus, the histological findings supported the diagnosis. Systemic evaluation revealed no occurrence of lymphoma in other areas. Her epiphora resolved, with a patent nasolacrimal duct irrigation 1 month after starting rituximab monotherapy.

\section{Discussion}

We reported a rare case of a primary MALT lymphoma of the lacrimal sac and documented clinical features in detail. As the lacrimal sac contains lacrimal drainage-associated lymphoid tissue which constitutes part of the mucosa-associated lymphoid tissue [5], MALT lymphoma may arise in the lacrimal sac. In fact, it is the commonest subtype occupying one third of all primary lacrimal sac lymphomas [6]. However, the clinical characteristics of this subtype are not fully known because only 8 cases have been reported in the English literature (table 1) [2, 6-8].

Epiphora with a swollen lacrimal sac wall is a diagnostic sign of a lacrimal sac tumor [3]. However, epiphora precedes tumor palpation for several months in lacrimal sac MALT lym- 
phoma [2, 3, 6-8]. Diagnosis of a lacrimal sac tumor is difficult without palpation, as epiphora is a nonspecific symptom which is also present in acquired nasolacrimal duct obstruction. Therefore, we need to include lacrimal sac tumor in the differential diagnosis in cases of epiphora with successful lacrimal syringing [3].

MRI is useful for qualitative diagnosis of the lesion. In this case, it also demonstrated a typical finding of ocular adnexal lymphoma to extraocular muscles as a slight hyperintensity on T1-weighted and T2-weighted images [9]. Fluid intensity in the center of the sac represented the patent lumen, which was consistent with intraoperative findings. As radiotherapy, chemotherapy and immunotherapy are effective in the treatment of lacrimal sac MALT lymphoma [2, 6-8], surgery should be limited to biopsy in order to avoid surgical complications. An exact preoperative diagnosis is necessary for proper surgical plan.

Intraoperative findings showed a thickened, pinkish gray mucosa that is typical for lacrimal sac lymphoma [2]. The pathological mucosa with a healthy outer wall suggested that the MALT lymphoma extended into the sac cavity first and outside of the wall next. This extending manner was consistent with the fact that the mucosa-associated lymphoid tissue localizes in the adenoid layer of the mucosa beneath the epithelial lining [10]. A lacrimal pump system failure resulting in epiphora was likely due to denatured sac mucosa despite of patent lumen macroscopically.

Chronic dacryocystitis needs to be differentiated from lacrimal sac MALT lymphoma. Chronic dacryocystitis occasionally demonstrates a nodular lymphoid infiltration pattern in subepithelial and intraepithelial areas, mimicking MALT lymphoma [11]. However, chronic dacryocystitis mostly shows diffuse infiltration pattern [12]. Increased goblet cell density and hyperplastic mucosal glands in cases with chronic dacryocystitis are also helpful for differential diagnosis [12]. In addition, the presence of round to cleaved centrocyte-like cells and positive immunoglobulin light chain (kappa or lambda) supported the diagnosis of MALT lymphoma in this case [13].

Lacrimal duct obstruction remains persistent in most reported cases despite regression of lymphomas after radiation and/or chemotherapy [1]. However, smooth lacrimal duct irrigation was noted in the present case. This could be due to incomplete obstruction of the lacrimal sac at the time of diagnosis. In addition, incisional biopsy by opening the sac did not result in secondary stenosis. Although radiotherapy was used in most reported cases [6-8], this treatment often induces lacrimal gland dysfunction, resulting in dry eyes [2, 14]. We preferred rituximab immunotherapy to avoid this complication.

In summary, we reported a rare case of a lacrimal sac MALT lymphoma found on epiphora without palpable mass. MRI was helpful in the qualitative diagnosis of this tumor. Diagnosis of this case before developing total obstruction resulted in successful preservation of the lacrimal drainage function.

\section{Statement of Ethics}

This study was approved by the Ethics Committee of Aichi Medical University Hospital and adhered to the tenets of the 1964 Declaration of Helsinki.

\section{Disclosure Statement}

The authors have no competing interests to declare. 
Kitaguchi et al.: Primary Marginal Zone B-Cell Lymphoma of the Mucosa-Associated Lymphoid Tissue of the Lacrimal Sac Found with Epiphora: A Case Report

\section{References}

1 Nakamura K, Uehara S, Omagari J, et al: Primary non-Hodgkin's lymphoma of the lacrimal sac. Cancer 1997;80:2151-2155.

-2 Schefler AC, Shields CL, Shields JA, et al: Lacrimal sac lymphoma in a child. Arch Ophthalmol 2003;121:1330-1333.

3 Jones IS: Tumors of the lacrimal sac. Am J Ophthalmol 1956;42:561-566.

-4 Peter NM, Khooshabeh R: Low-grade systemic lymphoma with aggressive transformation in the lacrimal sac. Eye 2012;26:886-887.

5 Kakizaki H: Anatomy, physiology, and immunology of the lacrimal system; in Ali MJ (ed): Principles and Practice of Lacrimal Surgery. Berlin, Springer, 2015, pp 17-33.

-6 Sjö LD, Ralfkiaer E, Juhl BR, et al: Primary lymphoma of the lacrimal sac: an EORTC ophthalmic oncology task force study. Br J Ophthalmol 2006;90:1004-1009.

7 Parmar DN, Rose GE: Management of lacrimal sac tumours. Eye 2003;17:599-606.

8 Kheterpal S, Chan SY, Batch A, et al: Previously undiagnosed lymphoma presenting as recurrent dacryocystitis. Arch Ophthalmol 1994;112:519-520.

-9 Cahill M, Barnes C, Moriarty P, et al: Ocular adnexal lymphoma: comparison of MALT lymphoma with other histological types. Br J Ophthalmol 1999;83:742-747.

$\checkmark 10$ Isaacson P, Wright DH: Extranodal malignant lymphoma arising from mucosa-associated lymphoid tissue. Cancer 1984;53:2515-2524.

11 Ali MJ, Mulay K, Pujari A, et al: Derangements of lacrimal drainage-associated lymphoid tissue (LDALT) in human chronic dacryocystitis. Ocul Immunol Inflamm 2013:21:417-423.

12 Bacon CM, Du MQ, Dogan AJ: Mucosa-associated lymphoid tissue (MALT) lymphoma: a practical guide for pathologists. Clin Pathol 2007;60:361-372.

13 Davids MS, Murali MR, Kuter DJ: Serum free light chain analysis. Am J Hematol 2010:85:787-790.

14 Paik JS, Cho WK, Lee SE, et al: Ophthalmologic outcomes after chemotherapy and/or radiotherapy in non-conjunctival ocular adnexal MALT lymphoma. Ann Hematol 2012;91:1393-1401. 


\section{Case Reports in Ophthalmology}

\begin{tabular}{l|l}
\hline Case Rep Ophthalmol 2016;7:148-154 \\
\hline DOI: 10.1159/000449121 & $\begin{array}{l}\text { ○ 2016 The Author(s). Published by S. Karger AG, Basel } \\
\text { www.karger.com/cop }\end{array}$ \\
\hline
\end{tabular}

Kitaguchi et al.: Primary Marginal Zone B-Cell Lymphoma of the Mucosa-Associated Lymphoid Tissue of the Lacrimal Sac Found with Epiphora: A Case Report
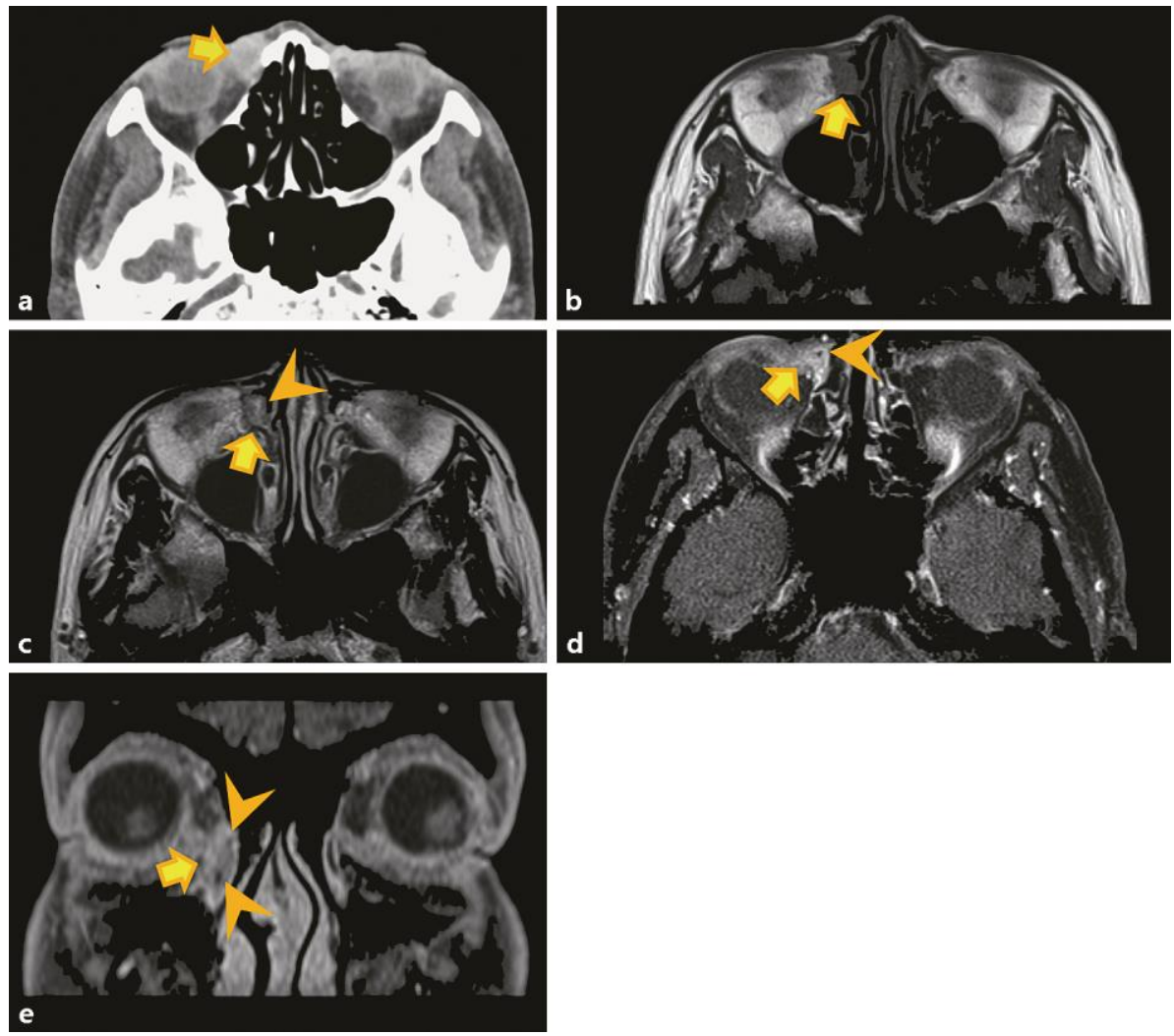

Fig. 1. Lymphoma of right lacrimal sac (arrows). a The CT scan showed a high-density mass without bony erosion. T1-weighted (b) and T2-weighted (c) axial images. Postcontrast T1-weighted axial (d) and coronal (e) images. Fluid in the lacrimal sac appeared as hyperintensity on T2-weighted, and as hypointensity on postcontrast T1-enhanced images (arrowheads).

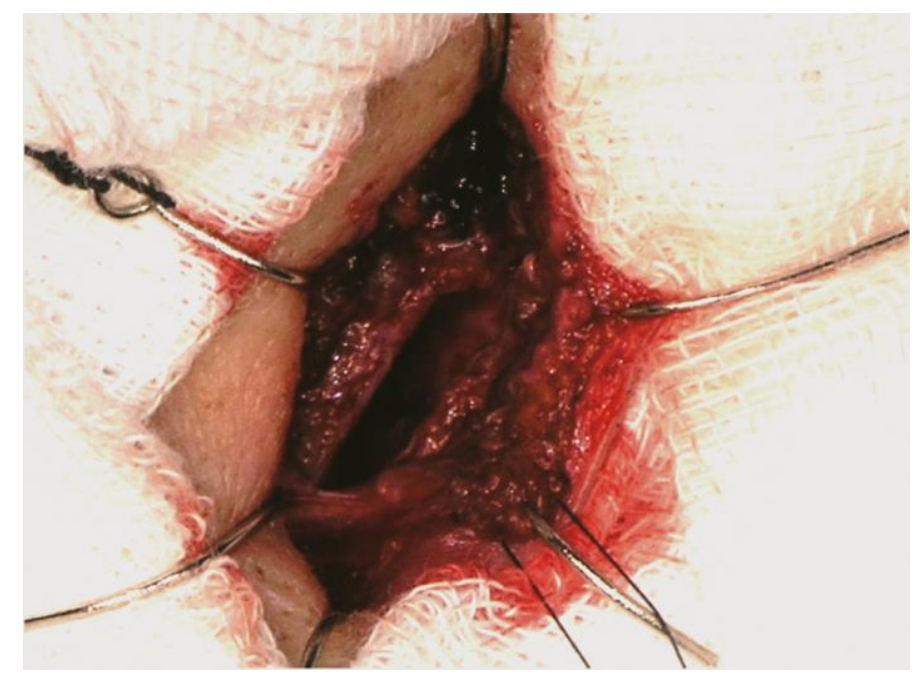

Fig. 2. Intraoperative finding. The mucosal wall of the lacrimal sac is markedly thickened with a patent lumen. 


\section{Case Reports in Ophthalmology}
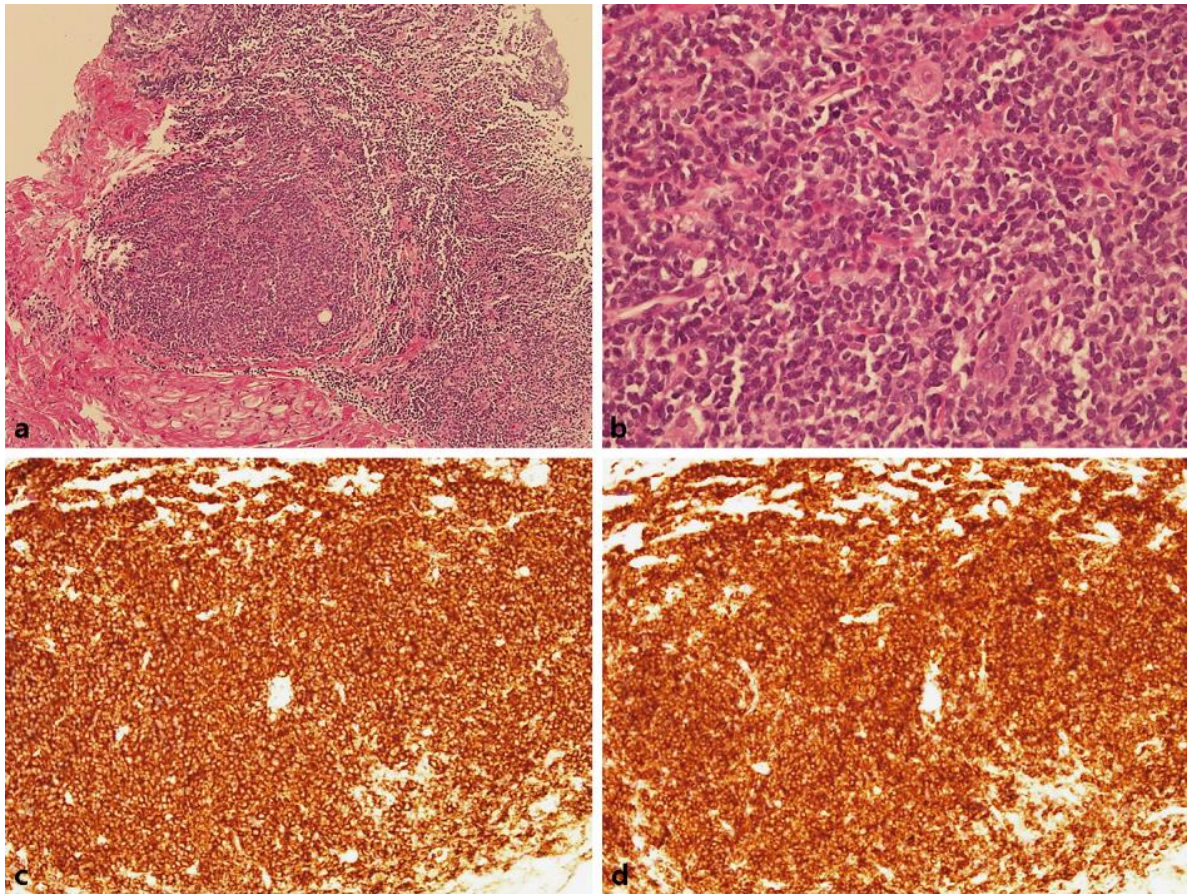

Fig. 3. Infiltration of small round to cleaved lymphocytes in the specimen from the lacrimal sac mucosa. a HE. $\times 40$. b HE. $\times 400$. Staining with an immunohistochemical marker of CD20 (original magnification $\times 200)(c)$, and CD79a (original magnification $\times 200$ ) $(d)$, consistent with the diagnosis of marginal zone Bcell lymphoma of the mucosa-associated lymphoid tissue. 
Kitaguchi et al.: Primary Marginal Zone B-Cell Lymphoma of the Mucosa-Associated Lymphoid Tissue of the Lacrimal Sac Found with Epiphora: A Case Report

Table 1. Our case and 8 reported cases of primary lacrimal sac MALT lymphoma

\begin{tabular}{|c|c|c|c|c|c|c|c|}
\hline Case & Source & Diagnosis & $\begin{array}{l}\text { Age, } \\
\text { years }\end{array}$ & Sex & Symptoms & Treatment & $\begin{array}{l}\text { Follow-up } \\
\text { (months) }\end{array}$ \\
\hline 1 & $\begin{array}{l}\text { Schefler et al. } \\
\text { [2] }\end{array}$ & MALT & 10 & M & $\begin{array}{l}\text { Epiphora ( } 1 \text { week), } \\
\text { painful swelling ( } 3 \text { weeks) }\end{array}$ & $\begin{array}{l}\text { Dacryocystorhinostomy } \\
\text { CHOP } \times 2\end{array}$ & Alive (30) \\
\hline 2 & Sjo et al. [6] & MALT & 93 & M & Epiphora, swelling & $\begin{array}{l}\text { Incomplete excision } \\
\text { Refused further treatment }\end{array}$ & Alive (12) \\
\hline 3 & Sjo et al. [6] & MALT & 71 & M & $\begin{array}{l}\text { Epiphora (over } 6 \text { months), } \\
\text { swelling }\end{array}$ & $\mathrm{RT}+\mathrm{CHOP} \times 6$ & $\begin{array}{l}\text { Relapse LN and } \\
\text { BM (8), dead, } \\
\text { cause unknown } \\
(120)\end{array}$ \\
\hline 4 & Sjo et al. [6] & MALT & 71 & $\mathrm{~F}$ & Epiphora, swelling & RT 45 Gy & Alive (144) \\
\hline 5 & $\begin{array}{l}\text { Parmar and } \\
\text { Rose [7] }\end{array}$ & MALT & 81 & $\mathrm{~F}$ & $\begin{array}{l}\text { Epiphora ( } 4 \text { months), sac } \\
\text { and canalicular mass }\end{array}$ & Chlorambucil & Alive (36) \\
\hline 6 & $\begin{array}{l}\text { Parmar and } \\
\text { Rose [7] }\end{array}$ & MALT & 56 & M & $\begin{array}{l}\text { Epiphora ( } 2 \text { months), inner } \\
\text { canthal mass }\end{array}$ & $\begin{array}{l}\text { RT } \\
\text { Dacryocystorhinostomy }\end{array}$ & Alive (46) \\
\hline 7 & $\begin{array}{l}\text { Parmar and } \\
\text { Rose [7] }\end{array}$ & MALT & 50 & $\mathrm{~F}$ & $\begin{array}{l}\text { Epiphora ( } 6 \text { months), inner } \\
\text { canthal mass }\end{array}$ & RT & Alive (16) \\
\hline 8 & $\begin{array}{l}\text { Kheterpal et al. } \\
\text { [8] }\end{array}$ & MALT & 82 & $\mathrm{~F}$ & $\begin{array}{l}\text { Epiphora (1 year), swelling, } \\
\text { recurrent dacryocystitis }\end{array}$ & RT & Alive (6) \\
\hline 9 & This case & MALT & 38 & $\mathrm{~F}$ & Epiphora & Rituximab & Alive (3) \\
\hline
\end{tabular}

LN = Lymph node; $\mathrm{BM}=$ bone marrow; $\mathrm{RT}=$ radiation therapy; $\mathrm{CHOP}=$ cyclophosphamide + doxorubicin + vincristine + prednisone. 